\title{
Antioxidant And Antibacterial Activities Of Methanol Extract Of Fig Fruit And Leaves (Ficus Carica L.)
}

\author{
Eva Agustina ${ }^{1}$, Nova Lusiana ${ }^{2 *}$, Risa Purnamasari ${ }^{3}$, Nurul Ilmi Faidah, Azlinda Mitha \\ Agustin
}

1,3,4,5 Prodi Biologi Fakultas Sains dan Tekhnologi, UIN Sunan Ampel Surabaya

${ }^{2}$ Fakultas Psikologi dan Kesehatan UIN Sunan Ampel Surabaya

Jl. Ahmad Yani No.117, Jemur Wonosari, Kec. Wonocolo, Kota Surabaya, Jawa Timur

*Corresponding author

Email: novalusiana@gmail.com

Keyword :

Antioxidant Antibacterial, Fig Plants

\begin{abstract}
Background: Fig plants (Ficus carica L.) have phytochemical contents such as polyphenols, flavonoids, and anthocyanins which are relatively high. The content of this active compound can be used as an antioxidant and antibacterial. Objectif: The study aims to determine the antioxidant and antibacterial activity of methanol extracts fruit and leaves of fig (Ficus carica L.). Methods : DPPH method was carried out to determine the antioxidant fruit and leaves of fig (Ficus carica L.) by observing the change in colour of the test sample after incubation with DPPH solution using a UV-Vis spectrophotometer at a wavelength of $517 \mathrm{~nm}$. The antibacterial test uses disc paper diffusion test to see the inhibition zone formed and continued with the MIC and MKC tests. Results : The antioxidant test results showed the IC50 values in methanol extracts of fig fruits were 13.402 ppm and 7.9875 ppm for fig leaves. From the IC50 value, both the fruit and fig leaves are classified into a solid antioxidant compound. The antibacterial test results showed that the highest inhibitory diameter was found at a 100\% concentration of 28.5 $\mathrm{mm}$. The quantitative antibacterial activity test showed that the methanol extract of fig fruit had a MIC value at a concentration of $80 \%$ and a MKC value at a concentration of $100 \%$. The optimal strength as an antibacterial from fruit extracts and leaves is $100 \%$ concentration. Conclusion: The results showed the methanol extract of fig (Ficus carica L.) has potential as an antioxidant and antibacterial compound.
\end{abstract}

\section{INTRODUCTION}

Antioxidants are compounds that can slow down, delay or inhibit an oxidation reaction. Antioxidant compounds themselves can fight free radicals or Reactive Oxygen Species (ROS), usually formed from the body's metabolic processes. Free radicals themselves are known to cause arteriosclerosis, ageing and cancer caused by tissue damage due to oxidation. ${ }^{1}$

Antibacterial is a compound that can kill non-pathogenic bacteria and pathogenic bacteria. Antibacterial compounds usually have toxic but selective properties which can kill parasites but do not occur in the host. ${ }^{2}$ One of the natural ingredients that can be used as a source of antioxidants and antibacterial compounds is figs (Ficus carica $L$.).

One of the common pathogenic bacteria found in human respiratory tract infections is Streptococcus pneumoniae, a gram-positive bacterium that inhabits normal flora in the upper respiratory tract. ${ }^{3}$ Pathogenic bacteria are bacteria that can infect and cause disease for living things that are their hosts. ${ }^{4}$ Streptococcus pneumoniae which is not common in humans, causes respiratory infections such 
as pneumonia, otitis, sinusitis, bronchitis, meningitis. Pneumonia is included in the Acute Lower Airway Infection located in the lung parenchyma cause high mortality. ${ }^{5}$ One of the common pathogenic bacteria found in human respiratory tract infections is Streptococcus pneumoniae, a gram-positive bacterium that inhabits normal flora in the upper respiratory tract. ${ }^{3}$ Pathogenic bacteria are bacteria that can infect and cause disease for living things that are their hosts. ${ }^{4}$ Streptococcus pneumoniae which is not common in humans, causes respiratory infections such as pneumonia, otitis, sinusitis, bronchitis, meningitis. Pneumonia is included in the Acute Lower Airway Infection located in the lung parenchyma cause high mortality. ${ }^{5}$ The second highest cause of under-five mortality in 2007 reached 30,470 under-five $(15.5 \% \quad \mathrm{x}$ $196.579)$ or if an average of 83 under-five died every day due to pneumonia. ${ }^{6}$

The use of antibiotics as a countermeasure can lead to bacterial immunity against the antibiotics themselves if their use is not as recommended, this results in an increase in the death rate due to infection. Currently, treatment and control of infectious diseases by bacteria are difficult to overcome because combined antibiotic drugs also causes antibiotic resistance. $^{7}$

Figs (Ficus carica L.) is a plant that has been used by the community as food and medicine for centuries. ${ }^{8,9}$. The benefits of the fruit, roots and leaves of Ficus carica L. are efficacious as a source of medicine in various diseases such as digestive disorders, diarrhoea, sore throat, cough, bronchitis, inflammation, cardiovascular system disorders and cancer. ${ }^{8-12 .}$

Previous studies have examined the phytochemical content and various bioactive compounds in the plant Ficus carica $L$. There are polyphenol, flavonoid, and anthocyanin compounds that have the ability as antioxidants and antibacterial agents. ${ }^{8,10,11,13-16 .}$ These phenolic compounds have an important role as antioxidants and antibacterial agents. ${ }^{17}$ Figs (Ficus carica L.) itself has a phenolic content equal to 1,090$1,110 \mathrm{mg} / 100 \mathrm{~g}$ of fresh fruit. ${ }^{18}$ The greater the phenolic compounds' range, the greater the antioxidant and antibacterial activity. ${ }^{17}$ Based on this background, a study was carried out to determine the action of the methanol extract of fig (Ficus carica L.) as an antioxidant and antibacterial compound.

\section{RESEARCH METHOD}

The materials used in this study were Figs (Ficus carica L.), methanol, sterile aquades, 5\% DMSO, $\mathrm{FeCl} 31 \%$, paper disks, Agar Nutrient Media (NA), Nutrient Borth (NB) media, ampicillin, pure culture of Streptococcus pneumonia, DPPH, Methanol PA. While the tools used in this study are beaker glass, plastic wrap, funnel, filter paper, stirring glass, stirrer, oven, analytical balance, rotary evaporator, measuring cup, Erlenmeyer, knife, blender, sieve, dropper, aluminium foil, autoclave plastic, autoclave, ose needle, test tube rack, vortex, test tube, bunsen, laminar airflow (LAF), incubator, fat cotton, petri dish, callipers, micropipette, label paper, UV-Vis spectrophotometer, Glass Cuvette, $50 \mathrm{ml}$ Pumpkin, Vial Bottle, Watch Glass.

Plant identification at the Kebun Raya Purwodadi Pusat Penelitian Botani, Lembaga Ilmu Pengetahuan Indonesia (LIPI), Purwodadi showed that the type of plant used as material for this study was Ficus carica L. Extraction

Fruit and leaves powder was extracted by maceration method using methanol as a solvent with a ratio between solvent and powder 4: 1. 250 grams of fig fruit and leaves powder were soaked with $1000 \mathrm{~mL}$ methanol for $2 \times 24$ hours by stirring $1 \times 24$ hours for 10 minutes. The results of the marinade are then filtered to separate the residue from the filtrate. The extract of fig fruit and leaves extract was then concentrated with a rotary evaporator for 2 hours. The extraction results that have been carried out on the extract of fig extracts obtained thick and dark brown concentrated extract. 


\section{Antioxidant Test}

Prepare a sample of 200 ppm master extract test figs with methanol PA and then do dilution with concentrations of $3,6,12.5$, 25, 50, 100, 200, 400, 800, 1000, 2000 ppm each of $5 \mathrm{ml}$ each in methanol PA. Prepare a solution of $100 \mathrm{ppm}$ DPPH stock. The solution of DPPH stock is prepared by dissolving $5 \mathrm{mg}$ of DPPH solid into $50 \mathrm{ml}$ of methanol PA. A comparison solution was then prepared, a control solution containing $3 \mathrm{ml}$ of methanol PA and $1 \mathrm{ml}$ of a $100 \mathrm{ppm}$ DPPH solution. For the test sample, each 1 ml sample solution $+1 \mathrm{ml} \mathrm{DPPH}$ solution + $2 \mathrm{ml} \mathrm{PA}$ methanol is prepared. Then, it was incubated for 30 minutes at $27{ }^{\circ} \mathrm{C}$ until the discolouration of DPPH activity occurred. All samples were extracted set samples tested for their absorbance values using a $\mathrm{UV}-\mathrm{V}$ is spectrophotometer at a wavelength of $517 \mathrm{~nm}$.

\section{Determination of the IC50 value}

Antioxidant testing of figs Fruit and leaves (Ficus carica L.) by DPPH method was conducted by observing the change in colour of the test sample after incubation with DPPH solution. If all DPPH electrons' reaction is paired with electrons in the extracted sample, there will be a change in the colour of the piece from dark purple to bright yellow. Then the absorbance value was measured using a UV-Vis spectrophotometer at a wavelength of 517 nm.

\section{Antibacterial Test Rejuvenation of Streptococcus pneumoniae bacteria}

Nutrient Agar (NA) Nutrient Media is heated, then poured into a Petri dish until solid. Pure cultures of Streptococcus pneumoniae bacteria were inoculated onto NA media. Media that have been inoculated and incubated for 24 hours until bacteria grow.

\section{Manufacture of Antibacterial Test Extract Concentrations}

The methanolic extract of figs was weighed on an analytical balance according to the concentration used, and then the extract was dissolved with $10 \mathrm{ml}$ of $5 \%$ DMSO solution.

\section{Antibacterial Activity Test}

Nutrient Agar (NA) media were poured into $20 \mathrm{ml}$ Petri dishes mixed with $200 \mu \mathrm{l}$ bacterial suspensions that had been measured with a light wave spectrophotometer of $600 \mathrm{~nm}$ with absorbance results of 0.1 , and then the media was shaken slowly until the homogeneous media was allowed to solidify. Disk paper is soaked in fig fruit and leaves extract which has been diluted according to concentration. Disc paper is placed on the surface and incubated for 24 hours in an incubator of $37^{\circ} \mathrm{C}$ until an inhibition zone is formed. Antibacterial test carried out by repetition three times. To determine the antibacterial activity of the inhibition zone formed is measured by callipers, the area of the inhibitory zone formed is measured by the formula:

$\mathrm{ZH}=\mathrm{ZK}-\mathrm{DC}$

Information :

$\mathrm{ZH}=$ Inhibition Zone

$\mathrm{ZK}=$ Overall Zone

$\mathrm{DC}=$ Disc Diameter

\section{Minimum Inhibitory Concentration Test (MIC)}

The Minimum Inhibitory Concentration Test (MIC) is carried out by a dilution method in which bacteria are planted on liquid media. Nutrient Borth (NB) is placed on a test tube as a normal test medium. The positive control was filled with $1 \mathrm{ml}$ of $\mathrm{NB}$, and $1 \mathrm{ml}$ of Streptococcus pneumoniae suspension and the negative control was filled with 1 gram of extract each fig and $1 \mathrm{ml}$ of NB. In another test tube filled with $1 \mathrm{ml}$ of sterile NB and added $0.5 \mathrm{ml}$ of Streptococcus pneumoniae bacterial suspension and each repeated three times. Before incubating the test solution, the absorbance was measured with a spectrophotometer at a wavelength of $600 \mathrm{~nm}$. Furthermore, it was incubated at $37^{\circ} \mathrm{C}$ for 24 hours, and the absorbance value was tested again. The formula measures the 
MIC value:

$\mathrm{MIC}=\mathrm{OD}$ after - OD before

Konsentrasi yang digunakan yaitu 1, 10, 20, 30, 40, 50, 50, 70, 80, 90 dan 100 dengan perbandingan control positif antibiotic ampicillin, suspense bakteri dan control negative dengan ekstrak buah dan daun tin

\section{Minimum Kill Concentration Test (MKC)}

Determination of the MKC test value with the whole solution stage from the MIC test was retested by taking one dose of each test solution then planted on the media on NA (Nutrient Agar) agar. All

cultures were incubated for 24 hours at $37^{\circ} \mathrm{C}$. After the incubation period can be read the results see the growth of bacteria on the media. The media concentration that did not show bacterial growth was MKC, which is the smallest concentration that could kill the test bacteria. ${ }^{19}$

The concentrations used were $1 \%$, $10 \%, 20 \%, 30 \%, 40 \%, 50 \%, 60 \%, 70 \%$, $80 \%, 90 \%$ and $100 \%$ with a positive control ratio of ampicillin antibiotics, bacterial suspense and negative control with fig fruit and leaves extracts.

\section{RESULT AND DISCUSSION}

\section{Antioxidant}

DPPH absorption method is one of the methods used in testing antioxidant activity. This method is relatively simple, it does not cost a lot, and the processing time is quite short. DPPH acts as a free radical where this test is based on the sample's ability as an antioxidant that can counteract free radicals. ${ }^{20}$ The study results showed that the samples of both the fruit methanol extract and the fig leaves that had reacted with DPPH experienced colour changes from purple to light purple to yellow. The colour change effected by DPPH has captured hydrogen atoms from antioxidant compounds in the sample. ${ }^{21}$

Based on the data that has been obtained at each concentration that has been tested using a UV-vis spectrophotometer with a wavelength of $517 \mathrm{~nm}$ and analyzed using linear regression where the figs fruit and leaves methanol extract produces the equation y and IC50 values as follows:

Table 1. IC50 Values (Ficus carica L.)

\begin{tabular}{ccc}
\hline Ekstract & Linear Regression & IC50 Value \\
\hline Fruit & $\mathrm{y}=3.6868 \mathrm{x}+0.5895$ & 13.402 \\
Leaves & $\mathrm{y}=7.2556 \mathrm{x}-7.1555$ & 7.9875
\end{tabular}

The value of IC50 in figs fruit methanol extract was 13,402 ppm while in fig leaves methanol extract was 7,9875 ppm. The IC50 value is included in the category of solid antioxidant activity because of the IC50 value $<50$ ppm. $^{22}$ Based on IC50 values produced, methanolic extracts of fig leaves showed better antioxidant activity in figs. This can occur because the quercetin content of fig leaves which is thought to act as an antioxidant is higher than the quercetin content of figs.Quercetin is a large group of antioxidants that are included in the flavonol derivative, in which flavonols themselves are part of flavonoids. ${ }^{23}$ Quercetin acts as an antioxidant by cutting the chain oxidation reaction in free radicals or capturing electrons in free radicals. ${ }^{24}$

Free radicals are atoms which are reactive and less stable. In achieving stability, free radicals have electrons which will interact by getting a pair. If free radicals do not get a partner and continuously take place, it can lead to a disease such as cancer. Therefore, the body needs an antidote to free radicals in the form of antioxidants, with IC50 values that have been obtained so that it can be said that the methanol extract of fruit and foliage in this study has the potential as an antioxidant.

\section{Antibacterial}


In the methanol extract of the fruit and fig leaves, each concentration showed different results in the inhibition zone formed, the higher the concentration, the greater the inhibition zone formed. This happens because it is influenced by the content of secondary metabolites which have an antibacterial role. ${ }^{25}$

The ability as an antibacterial for pathogenic bacteria Streptococcus pneumonia has been shown in both methanol extracts of figs fruit and leaves. The difference in terms of the inhibitory

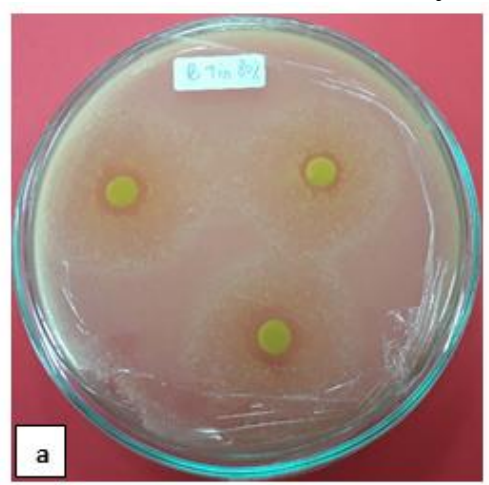

zone's diameter is due to the content of different secondary metabolite compounds in figs fruit and leaves. Secondary metabolites in figs fruit such as phenols and flavonoids while in fig leaves such as phenols, flavonoids and tannins. Although secondary metabolite content in fig leaves more, it does not produce a higher inhibition zone than figs fruit. This is because the phenol content of fresh figs is 1,090-1,110 mg / 100g. ${ }^{18}$ According to Pelczar and Chan (2008), one compound that can act as an antibacterial for pathogenic bacteria by damaging bacterial cell walls is phenol. ${ }^{26}$

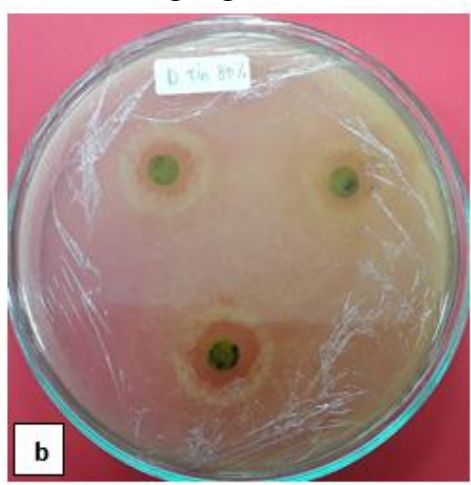

Figure 2. Comparison of inhibition zone diameters in methanol extracts of figs fruit (a) and leaves (b)

The comparison of inhibition zones that were formed on the methanol extract of fruit and leaves at each concentration can be seen in Figure 1. As follows:

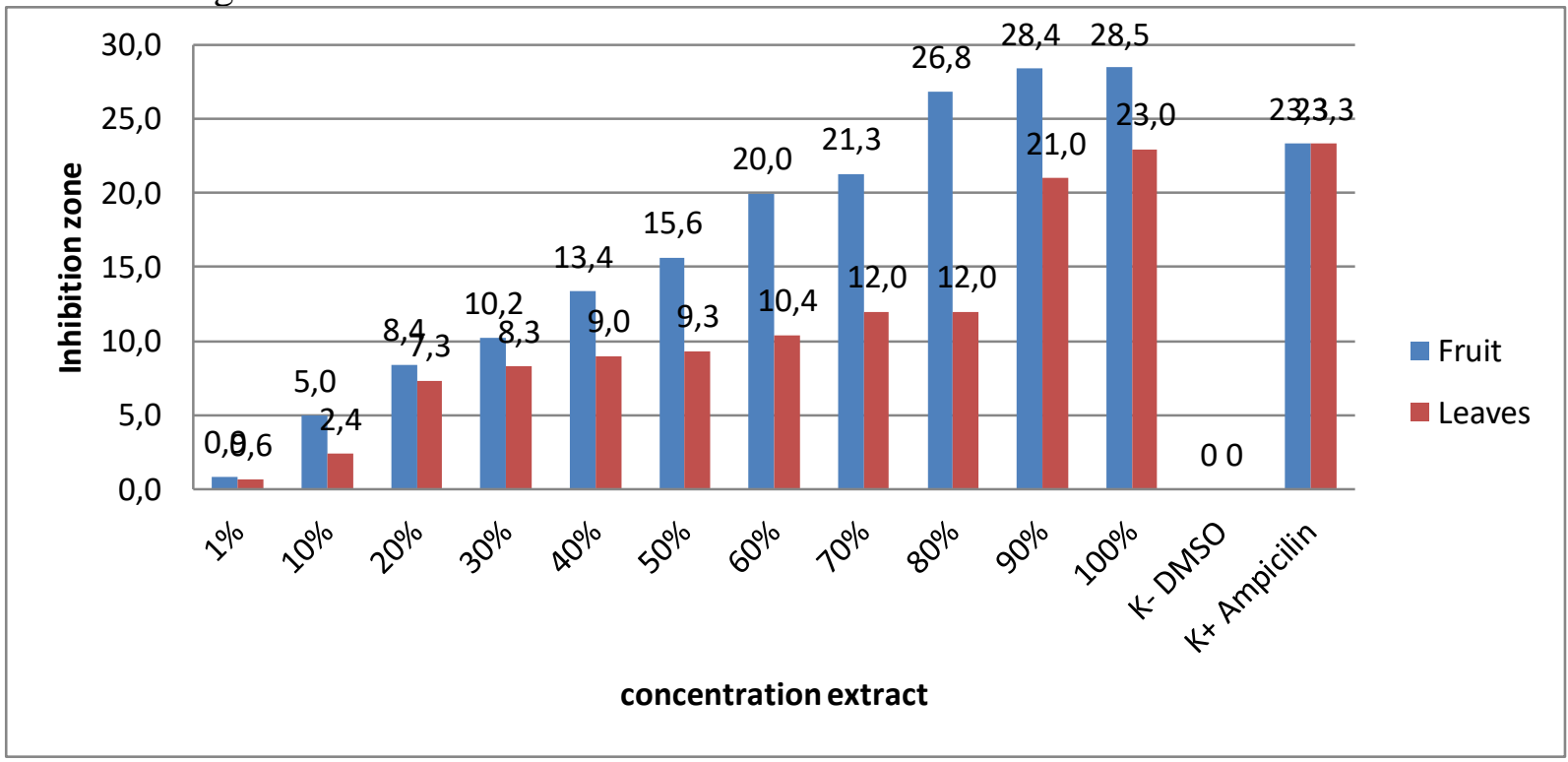

Figure 1. Comparison of inhibition zones in methanol extracts of fruit and tin leaves 
Statistical testing is done in stages after the results obtained from the inhibition zone formed from the ShapiroWilk normality test to Mann-Whitney. The final results of statistical tests using MannWhitney obtained $\mathrm{p}$ value> 0.05 . This value indicates that the inhibition zone's diameter between the two concentrations in the sample of both methanol extracts of fig fruit and leaves did not differ significantly. Mann-Whitney test results obtained showed that the higher concentration of extracts tested could affect the resulting inhibition zone. Extract concentration is related to metabolite compounds that act as an antibacterial, where the content of these compounds at high concentrations will be far more than low concentrations. ${ }^{27}$

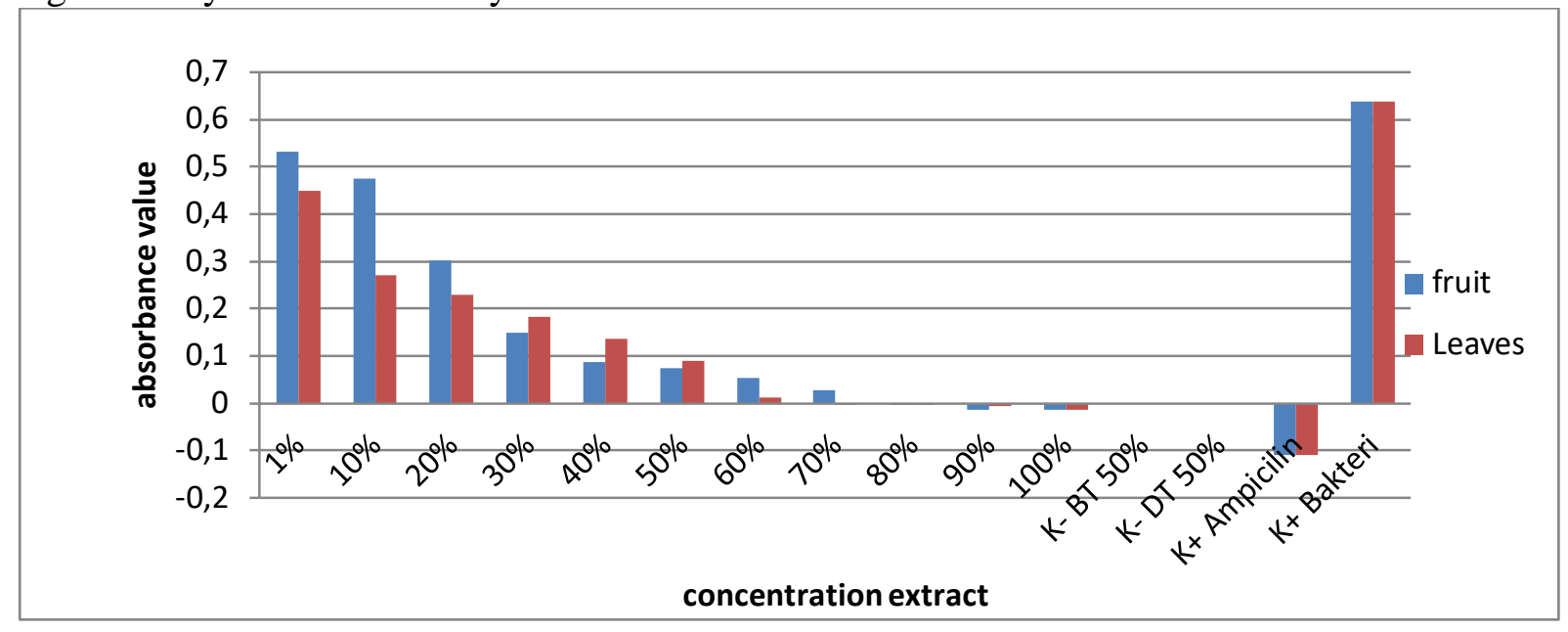

Figure 3. absorbance value of MIC test

The MIC test was statistically tested by using Paired Sample T-Test and obtained a p-value of 0.00 in both samples. This indicates a significant difference in absorbance values. The absorbance value in the MIC test has increased and decreased due to bacterial growth and death caused by the extracted test. The results obtained in the MIC test, the higher the concentration, the lower the absorbance value, and the lower the concentration, the higher the absorbance. In this case, the bacterial growth activity is still visible. The difference in the effect obtained at each concentration can occur because of the lower the concentration, the lower the secondary metabolite level as antibacterial, so that the ability to inhibit it is getting weaker. ${ }^{27}$ The concentrations that were determined as the minimum inhibitory concentration (MIC) in this study were $80 \%$ concentration in the methanol extract of figs and $70 \%$ in the methanol extract of figs leaves.
The MKC test (The minimum concentration of kills) aims to determine the minimum concentration that can kill the pathogenic bacteria Streptococcus pneumoniae in the methanol extract of the fruit and leaves of fig. The test results show that both the methanol extract of figs fruit and leaves the concentration set as MKC is a concentration of $100 \%$. This can be said as MKC because at this concentration there was no bacterial colony growing on the media, while concentrations below $100 \%$ found a white, cloudy bacterial colony (Figure 4).In the MKC test, the two extracts had the ability to kill pathogenic Streptococcus pneumoniae bacteria. This ability is none other than due to the presence of secondary metabolites in the form of quite high phenols. In figs plants the content of phenol derivatives that can act as antibacterials, namely flavonoids, tannins, polyphenols, and anthocyanins., ${ }^{3,5,6,8-11 .}$ 


\section{CONCLUSIONS}

A methanol extract of fig fruit and leaves with IC50 values of 13,402 ppm and $7,9875 \mathrm{ppm}$, had very strong antioxidant activity. Figs fruit extracts and leaves also can be antibacterial as indicated by inhibition zone values, MIC and MKC. The highest inhibitory diameter was found at a concentration of $100 \%$ of $28.5 \mathrm{~mm}$. The optimal level as an antibacterial from fruit extracts and leaves is $100 \%$ concentration.

\section{ACKNOWLEDGMENT}

Thanks to the Integrated Laboratory of UIN Sunan Ampel Surabaya as a place of research.

\section{REFERENCES}

1. Miryanti YA, Sapei L, Budiono K, Indra S. Ekstraksi Antioksidan Dari Kulit Buah Manggis (Garcinia mangostana L. Research ReportEngineering Science. 2011;2.

2. Xia E-Q, Deng G-F, Guo Y-J, Li HB. Biological activities of polyphenols from grapes. International Journal of Molecular Sciences. 2010;11(2):622-46.

3. Suharjono, T Y, Sumarno, J SS. Studi Penggunaan Antibiotika Pada Penderita Rawat Inap Pneumonia (Penelitian Di Sub Departemen Anak Rumkital Dr. Ramelan Surabaya). Pharmaceutical Sciences and Research (PSR). 2012 Aug 14;6(3):142-155-155.

4. Pulungan ASS, Brata Www. Aktivitas Antibakteri Ekstrak Etanol Daun Talas Terhadap Bakteri Patogen. JURNAL PENELITIAN SAINTIKA. 2019 Feb 16;17(2):76-9.

5. Kementerian Kesehatan Republik Indonesia [Internet]. [cited $2021 \mathrm{Feb}$ 18]. Available from: https://www.kemkes.go.id/folder/vie w/01/structure-publikasi-pusdatinprofil-kesehatan.html
6. Kefarmasian DP dan D. Farmakope Herbal Indonesia Edisi II Tahun 2017 | Direktorat Jenderal Kefarmasian dan Alat Kesehatan [Internet]. [cited 2021 Feb 18]. Available from: http://farmalkes.kemkes.go.id/2020/0 8/farmakope-herbal-indonesia-edisiii-tahun-2017-3/

7. Adelberg JM\&. Jawetz, Melnick \& Adelberg's Mikrobiologi Kedokteran (Buku 1). Edisi 1. Salemba Medika; 2005.

8. Jeong M-R, Kim H-Y, Cha J-D. Antimicrobial activity of methanol extract from Ficus carica leaves against oral bacteria. Journal of Bacteriology and Virology. 2009;39(2):97-102.

9. Standardization ISO] IO. Microbiology of Food and Animal Feeding Stuffs: Horizontal Method for the Enumeration of Microorganisms. 2003.

10. Essid A, Aljane F, Ferchichi A, Hormaza JI. Analysis of genetic diversity of Tunisian caprifig (Ficus carica L.) accessions using simple sequence repeat (SSR) markers. Hereditas. 2015;152(1):1.

11. Saleh B, Hammoud R, Al-Mariri A. Antimicrobial activity of Ficus sycomorus L.(Moraceae) leaf and stem-bark extracts against multidrug resistant human pathogens. Herba Polonica. 2015;61(1):39-49.

12. Rahmani AH, Aldebasi YH. Ficus carica and its constituents role in management of diseases. Asian J Pharm Clin Res. 2017;10(6):49-53.

13. Aref HL, Mosbah H, Louati H, Said K, Selmi B. Partial Characterization Of A Novel Amylase Activity Isolated From Tunisian Ficus carica latex. Pharmaceutical Biology. 2011;49(11):1158-66.

14. Basualdo C, Sgroy V, Finola MS, Marioli JM. Comparison of the antibacterial activity of honey from different provenance against bacteria usually isolated from skin wounds. 
Veterinary Microbiology. 2007;124(3-4):375-81.

15. Aref HL, Salah K, Chaumont JP, Fekih A, Aouni M, Said K. In vitro antimicrobial activity of four Ficus carica latex fractions against resistant human pathogens (antimicrobial activity of Ficus carica latex. Pak J Pharm Sci. 2010;23(1):53-8.

16. Rashid KI, Mahdi NM, Alwan MA, Khalid LB. Antimicrobial activity of fig (Ficus carica Linn.) leaf extract as compared with latex extract against selected bacteria and fungi. Journal of University of Babylon. 2014;22(5):1620-6.

17. D. S, Shafiq-ur-Rehman. AN, S. U, M.A R. Antioxidant Activities of the Selected Plants from the Family Euphorbiaceae, lauraceae, Malvaceae and Balsaminaceae. African Journal of Biotechnology. 2010;9(7):108696.

18. Vinson JA, Zubik L, Bose P, Samman N, Proch J. Dried fruits: Excellent in vitro and in vivo antioxidants. Journal of the American College of Nutrition. 2005;24(1):4450.

19. Affandi A, Fauzia A, L SD. Penentuan Konsentrasi Hambat Minimal dan Konsentrasi Bunuh Minimal Larutan Povidon Iodium 10\% Terhadap Staphylococcus aureus Resisten Metsilin (MRSA) dan Staphylococcus aureus Sensitif Metsilin (MSSA. JIK. 2008;3(1):149.

20. Agustina E. Uji Aktivitas Senyawa Antioksidan Dari Ekstrak Daun Tiin (Ficus Carica Linn) Dengan Pelarut Air, Metanol Dan Campuran Metanol-Air. Vol. 1. KLOROFIL: Jurnal Ilmu Biologi Dan Terapan; 2017.

21. Szabo M, Idiţoiu C, Chambre D, Lupea A. Improved DPPH determination for antioxidant activity spectrophotometric assay. Chemical Papers. 2007;61(3):214-6.
22. Zuhra CF, Tarigan JB, Sihotang H. Aktivitas antioksidan senyawa flavonoid dari daun katuk. 2008.

23. Cook N, Samman S. Flavonoids: Chemistry, metabolism, cardioprotective effects and dietary sources. Nutritional Biochemistry. 1996;7:66-76.

24. Winarsi H. Antioksidan Alami \& Radikal Bebas: Potensi dan Aplikasinya dalam Kesehatan. Yogyakarta: Penerbit Kanisius; 2007.

25. Jawa T. Uji Daya Hambat Antibakteri Ekstrak Umbi Bawang Merah (Allium $\begin{array}{lll}\text { ascalonicum } & \text { L.) } & \text { Terhadap }\end{array}$ Pertumbuhan Bakteri Pembentuk Karies Gigi Streptococcus mutans. Yogyakarta: Skripsi. Universitas Sanata Darma; 2016.

26. Pelczar MJ, Chan ESC. Dasar- dasar Mikrobiologi 2. Ratna SH dkk, penerjemah: Jakarta: UI Pr. Terjemahan dari: Elements of Microbiology. Sirait M. 2008;

27. Ajizah A. Sensitivitas Salmonella typhimurium terhadap ekstrak daun Psidium guavaja L. In: Program Studi Pendidikan Biologi FKIP Universitas Lambung Mangkurat. Samarinda; 2004. 